\title{
The Orthogonal Response of Stock Returns to Dividend Yield and Price-to-Earnings Innovations
}

\author{
Vichet Sum \\ School of Business and Technology, University of Maryland, Eastern Shore \\ Kiah Hall, Suite 2117-A Princess Anne, MD 21853, USA \\ Tel: 1-410-651-6531 E-mail:vsum@umes.edu
}

Received: Decemer 3, 2012

Accepted: December 24, 2012

Online Published: January 9, 2013

doi:10.5430/afr.v2n1p47

URL: http://dx.doi.org/10.5430/afr.v2n1p47

\begin{abstract}
This study investigates how returns on the S\&P 500 index respond orthogonally to dividend yield and price-to-earnings innovations. The unrestricted vector autoregressive (VAR) analysis of monthly data from 1871 to 2012 shows that the response of returns on the S\&P 500 index to dividend yield innovation, based on the 12-month horizon, is positive in the first three months, negative in the 4th through 7 th months and positive again after that. The returns on the S\&P 500 index are negative in the first five months following price-to-earnings shock. The results of the Granger causality tests indicate that dividend yield and price-to-earnings cause the movement in stock returns.
\end{abstract}

Keywords: S\&P 500 returns, Dividend yield, Price-to-earnings ratio

\section{Introduction}

Dividend yield and price-to-earnings ratio, among other factors, have been shown to have a predictive power in explaining stock returns. Many studies have reported a positive association between stock returns and dividend yields despite the claim made by Black and Scholes (1974) and Miller and Scholes (1982) that there is no relation between equilibrium returns and dividend yields. Blume (1980) empirically documents a positive and significant relationship between stock returns and dividend yields.In addition, Litzenberger and Ramaswamy (1982) and Morgan (1982) provide evidence of a positive and nonlinear relationship between stock returns and expected dividend yields.Kiem (1985) reports the association between stock returns and dividend yields; the relationship is due to a nonlinear association between returns in the month of January and dividend yields.Campbell and Shiller (1988) examine the relationship between dividend yields and stock returns in the introduction of the dividend yield model.Fama and French (1988) show that stock returns can be predicted by dividend yields.Hodrick (1992) reports that changes in dividend yields significantly forecast expected stock returns. The relationship between returns and dividend yield is also documented in a study conducted by Naranjo, Nimalendran and Ryngaert (1998). Jiang and Lee (2007) also show excess stock returns can be predicted by a linear combination of log book-to-market ratio and $\log$ dividend yields. The relationship between stock returns and price-to-earning (P/E) ratio has also been studied. Basu (1977) empirically shows that lower P/E stock portfolios generate higher risk-adjusted returns than portfolios of high P/E stocks. A similar finding is reported in a study conducted by Peavy and Goodman (1983). Campbell and Shiller (1998) show the increase in P/E ratio are followed by the lower growth in stock price.

Due to the empirical establishment in the literature that stock returns can be predicted by dividend yield and price-to-earnings among many other factors, the current study is to add to current discussion by investigating how returns on the S\&P 500 index respond orthogonally to dividend yield and price-to-earning innovations and to determine if dividend yield and price-to-earning cause the movement in stock returns. This study is important because it contributes to furthering the understanding of the dynamic effects of dividend yields and price-to-earnings on stock returns. The strength of this study is a richer dataset spanning from 1871 to 2012 and the use of vector autoregressive framework to forecast the behavior of future stock returns following dividend yield and price-to-earnings shocks.

\section{Method and Data}

The paper investigates how returns on the S\&P 500 index respond orthogonally to dividend yield and price-to-earning innovations and to conduct a causality test among these variables. The vector autoregressive (VAR) analysis, a system of equations (1), (2), (3), is employed to investigate how stock returns respond to dividend yield 
and price-to-earnings shocks; then the Granger Causality Walt Tests are conducted to determine the causal linkage among these variables. In addition, based on the results of the Augmented Dickey-Fuller and Phillips-Perron unit root tests reported in Table 1, the variables included in the VAR do not have unit roots, so they are stationary. The monthly data spanning from 1871 to 2012 of the total returns on the S\&P 500 and dividend yield and price-to-earnings ratio of the S\&P 500 are obtained from the Global Financial Data. "All earnings data are based upon the trailing 12 months. The monthly file takes the reported earnings for each quarter then calculates the P/E based upon the closing price for each month. Since it takes a few months to get the earnings figures for the previous quarter, this data is only available a few months after the fact," Global Financial Data, 2012.

$$
\begin{gathered}
R_{t}=\alpha+\sum_{i=1}^{n} \lambda_{i} R_{t-i}+\sum_{i=1}^{n} \delta_{i} D Y_{t-i}+\sum_{i=1}^{n} \varphi_{i} P E_{t-i}+\varepsilon_{t} \\
D Y_{t}=\alpha+\sum_{i=1}^{n} \lambda_{i} R_{t-i}+\sum_{i=1}^{n} \delta_{i} D Y_{t-i}+\sum_{i=1}^{n} \varphi_{i} P E_{t-i}+\varepsilon_{t} \\
P E_{t}=\alpha+\sum_{i=1}^{n} \lambda_{i} R_{t-i}+\sum_{i=1}^{n} \delta_{i} D Y_{t-i}+\sum_{i=1}^{n} \varphi_{i} P E_{t-i}+\varepsilon_{t}
\end{gathered}
$$

Where:

$\mathrm{R}_{\mathrm{t}}=$ total return on the $\mathrm{S} \& \mathrm{P} 500$ index in month $\mathrm{t}$

$\mathrm{R}_{\mathrm{t}-\mathrm{i}}=$ total return on the S\&P 500 index in month $\mathrm{t}-\mathrm{i}$

$\mathrm{DY}_{\mathrm{t}}=$ dividend yield of the S\&P 500 index in month $\mathrm{t}$

$\mathrm{DY}_{\mathrm{t}-\mathrm{i}}=$ dividend yield of the S\&P 500 index in month $\mathrm{t}-\mathrm{i}$

$\mathrm{PE}_{\mathrm{t}}=$ price-to-earnings ratio of the $\mathrm{S} \& \mathrm{P} 500$ index in month $\mathrm{t}$

$\mathrm{PE}_{\mathrm{t}}=$ price-to-earnings ratio of the $\mathrm{S} \& \mathrm{P} 500$ index in month $\mathrm{t}-\mathrm{i}$

\section{Results}

Descriptive statistics and correlations of the variables are reported in Table 2 and 3. Before running the vector autoregressive analysis, the Schwarz's Bayesian information criterion (SBIC), the Akaike's information criterion (AIC), and the Hannan and Quinn information criterion (HQIC) tests are conducted to determine the appropriate length of lags to be included.Ten lags are suggested by the tests. First of all, the response of returns on the S\&P 500 index to dividend yield innovation, based on the 12-month horizon, is positive in the first three months, negative in the 4th through 7th months and positive again after that (See Figure 4 and Table 4). The returns on the S\&P 500 index are negative in the first five months following price-to-earning shock (See Figure 5 and Table 5). The results of the Granger causality tests reported in Table 6 indicate that dividend yield and price-to-earnings cause the movement in stock returns. Based on the stability condition check (not reported here), the VAR estimates satisfy stability condition because all the eigenvalues lie inside the unit circle.

\section{Conclusion}

This study investigates how returns on the S\&P 500 index respond orthogonally to dividend yield and price-to-earning innovations. The unrestricted vector autoregressive (VAR) analysis of monthly data from 1871 to 2012 shows that the response of returns on the S\&P 500 index to dividend yield innovation, based on the 12-month horizon, is positive in the first three months, negative in the 4th through 7th months and positive again after that. The returns on the S\&P 500 index are negative in the first five months following price-to-earning shock. The Granger causality tests indicate a causal link between returns on the S\&P 500 index, dividend yield and price-to-earnings. This study is important because it contributes to furthering the understanding of the dynamic effects of dividend yields and price-to-earnings on stock returns. This study uses a richer dataset spanning from 1871 to 2012 and employs the vector autoregressive framework to forecast the behavior of future stock returns following dividend yield and price-to-earnings shocks.

\section{References}

Basu, S. (1977). Investment performance of common stocks in relation to their price-earningsratios: A test of the efficient market hypothesis. The Journal of Finance, 32(3), 663-682. http://dx.doi.org/10.1111/j.1540-6261.1977.tb01 979.x

Black, F., \& Scholes, M. (1974). The effects of dividend yield and dividend policy on common stock prices and returns.Journal of Financial Economics, 1(1), 1-22. http://dx.doi.org/10.1016/0304-405X(74)90006-3

Blume, M. E. (1980). Stock returns and dividend yields: Some more evidence. The Review of Economics and Statistics, 62(4), 567-577. http://dx.doi.org/10.2307/1924781

Campbell, J. Y., \& Shiller, R. J. (1988). The dividend-price ratio and expectations of future dividends and discount factors. Review of Financial Studies, 1(3), 195-228. http://dx.doi.org/10.1093/rfs/1.3.195 
Campbell, J. Y., \& Shiller, R. J. (1988). Valuation ratios and the long-run stock market outlook. Journal of Portfolio Management, 24(2), 11-26. http://dx.doi.org/10.3905/jpm.24.2.11

Fama, E. F., \& French, K. R. (1988). Dividend yields and expected stock returns. Journal of Financial Economics, 22(1), 3-25. http://dx.doi.org/10.1016/0304-405X(88)90020-7

Hodrick, R. J. (1992). Dividend yields and expected stock returns: Alternative procedures for inference and measurement. Review of Financial studies, 5(3), 357-386. http://dx.doi.org/10.1093/rfs/5.3.357

Jiang, X., \& Lee, B. S. (2007). Stock returns, dividend yield, and book-to-market ratio. Journal of Banking \& Finance, 31(2), 455-475. http://dx.doi.org/10.1016/j.jbankfin.2006.07.012

Keim, D. B. (1985). Dividend yields and stock returns: Implications of abnormal January returns. Journal of Financial Economics, 14(3), 473-489. http://dx.doi.org/10.1016/0304-405X(85)90009-1

Litzenberger, R. H., \& Ramaswamy, K. (2012). The effects of dividends on common stock prices tax effects or information effects? The Journal of Finance, 37(2), 429-443. http://dx.doi.org/10.1111/j.1540-6261.1982.tb0356 5.x

Miller, M. H., \& Scholes, M. S. (1982). Dividends and taxes: Some empirical evidence. The Journal of Political Economy, 1118-1141.

Morgan, I. G. (1982). Dividends and capital asset prices. The Journal of Finance, 37(4), 1071-1086. http://dx.doi.org/10.1111/j.1540-6261.1982.tb03565.x

Naranjo, A., Nimalendran, M., \& Ryngaert, M. (1998). Stock returns, dividend yields, and taxes. The Journal of Finance, 53(6), 2029-2057. http://dx.doi.org/10.1111/0022-1082.00082

Peavy III, J. W., \& Goodman, D. A. (1983). The significance of P/Es for portfolio returns. The Journal of Portfolio Management, 9(2), 43-47. http://dx.doi.org/10.3905/jpm.1983.408908

Table 1. Augmented Dickey-Fuller and Phillips-Perron Unit Root Tests

\begin{tabular}{lcccccc}
\hline & \multicolumn{3}{c}{$\begin{array}{c}\text { Augmented Dickey-Fuller } \\
\text { Unit Root Test (10 Lags) }\end{array}$} & \multicolumn{3}{c}{ Phillips-Perron Unit Root Test } \\
\hline Variable & $\mathrm{R}$ & $\mathrm{PE}$ & $\mathrm{DY}$ & $\mathrm{R}$ & $\mathrm{PE}$ & $\mathrm{DY}$ \\
$\mathrm{Z}(\mathrm{t})$ & -11.11 & -6.17 & -4.74 & -36.545 & -7.722 & -42.659 \\
$\mathrm{Z}(\mathrm{rho})$ & & & & -1449.18 & -116.741 & -4.631 \\
MacKinnon p-value & 0.0000 & 0.0000 & 0.0006 & 0.0000 & 0.0000 & 0.0009 \\
Trend Term Included & $\mathrm{NO}$ & $\mathrm{NO}$ & YES & NO & NO & YES \\
Unit Root & NO & NO & NO & NO & NO & NO \\
\hline
\end{tabular}

Table 2. Descriptive Statistics

\begin{tabular}{lccc}
\hline & R & DY & PE \\
\hline Number of Observations & 1699 & 1699 & 1699 \\
Mean & 0.81 & 4.27 & 15.98 \\
Maximum & 42.89 & 9.63 & 122.41 \\
Minimum & -29.63 & 1.08 & 5.21 \\
Standard Deviation & 4.81 & 1.51 & 8.93 \\
Skewness & 0.34 & 0.25 & 6.43 \\
Kurtosis & 13.55 & 2.95 & 67.38 \\
\hline
\end{tabular}


Table 3. Correlations

\begin{tabular}{lccc}
\hline & $\mathbf{R}$ & DY & PE \\
\hline $\mathbf{R}$ & 1.000 & & \\
DIV & -0.083 & 1.000 & \\
$\mathbf{P E}$ & 0.013 & -0.440 & 1.000 \\
\hline
\end{tabular}

Table 4. The Orthogonal Impulse Response Function (OIRF) of the Returns on the S\&P 500 Index to Dividend Yield Shock

\begin{tabular}{ccc}
\hline Horizon (In Month) & OIRF & Standard Error \\
\hline 1 & 0.064 & 0.113 \\
2 & 0.232 & 0.114 \\
3 & 0.108 & 0.113 \\
4 & -0.083 & 0.114 \\
5 & -0.212 & 0.113 \\
6 & -0.029 & 0.114 \\
7 & -0.144 & 0.114 \\
8 & 0.063 & 0.114 \\
9 & 0.201 & 0.113 \\
10 & 0.029 & 0.032 \\
11 & 0.038 & 0.032 \\
12 & 0.017 & 0.031 \\
\hline
\end{tabular}

Table 5. The Orthogonal Impulse Response Function (OIRF) of the Returns on the S\&P 500 Index to Price-to-Earnings Shock

\begin{tabular}{ccc}
\hline Horizon (In Month) & OIRF & Standard Error \\
\hline 1 & -0.116 & 0.113 \\
2 & -0.025 & 0.113 \\
3 & -0.261 & 0.113 \\
4 & -0.291 & 0.108 \\
5 & 0.057 & 0.108 \\
6 & 0.314 & 0.108 \\
7 & 0.126 & 0.093 \\
8 & 0.006 & 0.093 \\
9 & -0.093 & 0.092 \\
10 & 0.130 & 0.064 \\
11 & -0.019 & 0.062 \\
12 & -0.153 & 0.062 \\
\hline
\end{tabular}


Table 6. Granger Causality Walt Tests

\begin{tabular}{cccc}
\hline \multirow{2}{*}{ Regressors } & \multicolumn{3}{c}{ Dependent Variables } \\
\cline { 2 - 4 } & $\boldsymbol{R}$ & $\boldsymbol{D} \boldsymbol{P}$ & $\mathbf{P E}$ \\
\hline $\boldsymbol{R}$ & 0.001 & 0.000 & 0.000 \\
$\boldsymbol{n y}$ & 0.050 & 0.000 & 0.003 \\
$\boldsymbol{P E}$ & 0.011 & 0.067 & 0.000 \\
\hline
\end{tabular}

The p-values for F-statistics for joint tests on lags are reported here

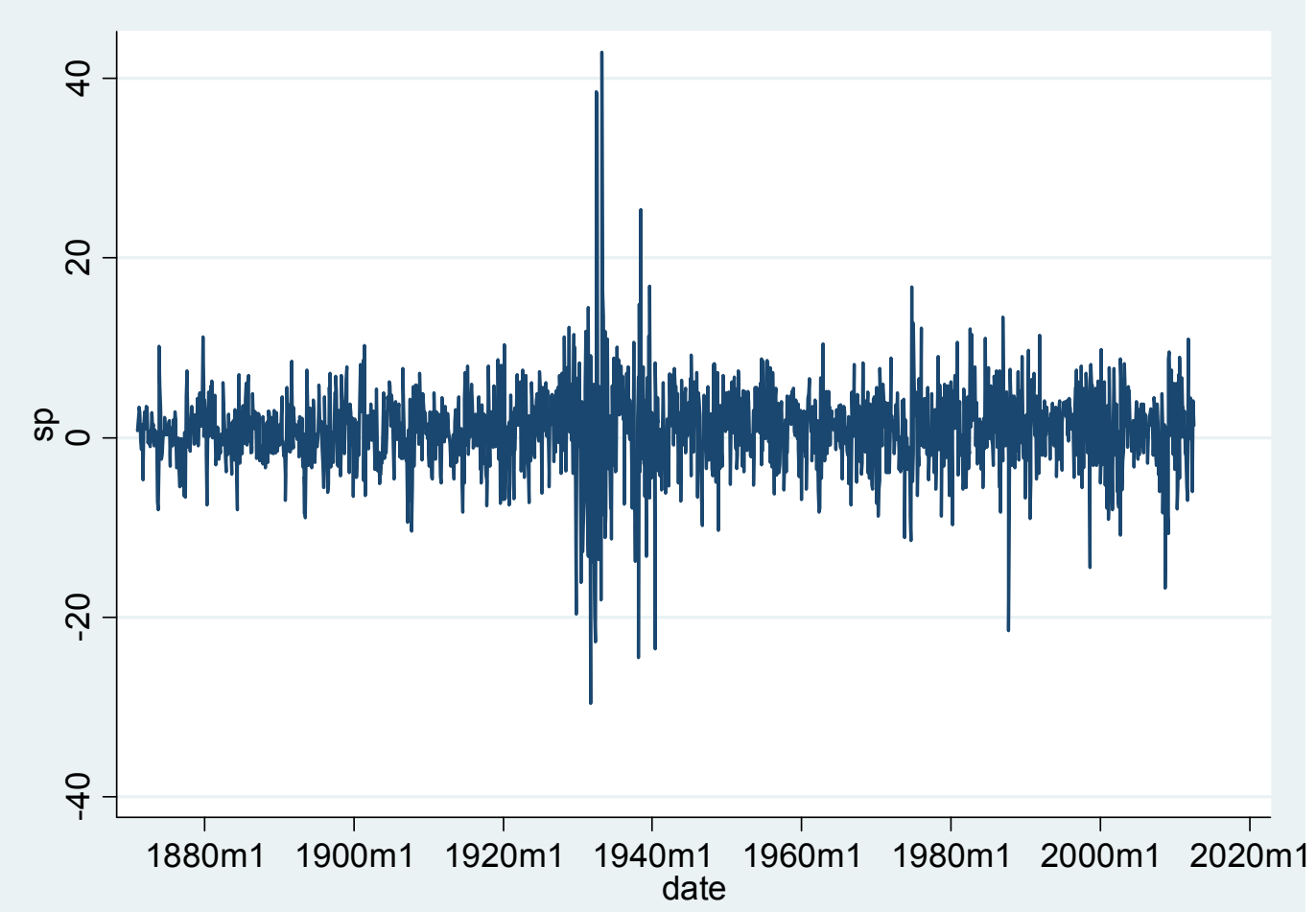

Figure 1. Returns on the S\&P 500 Index 


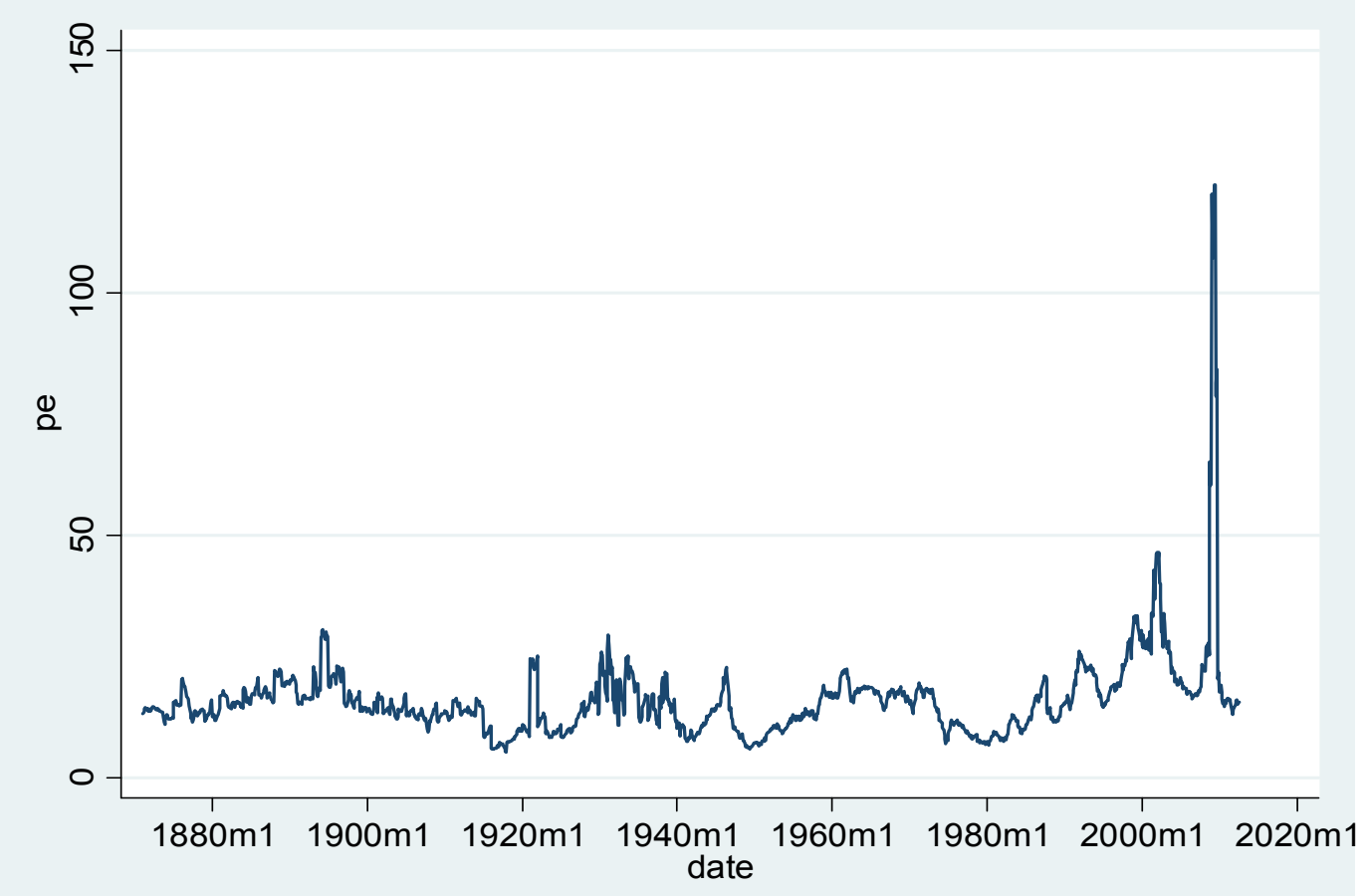

Figure 2.S\&P 500 Price-Earnings Ratio

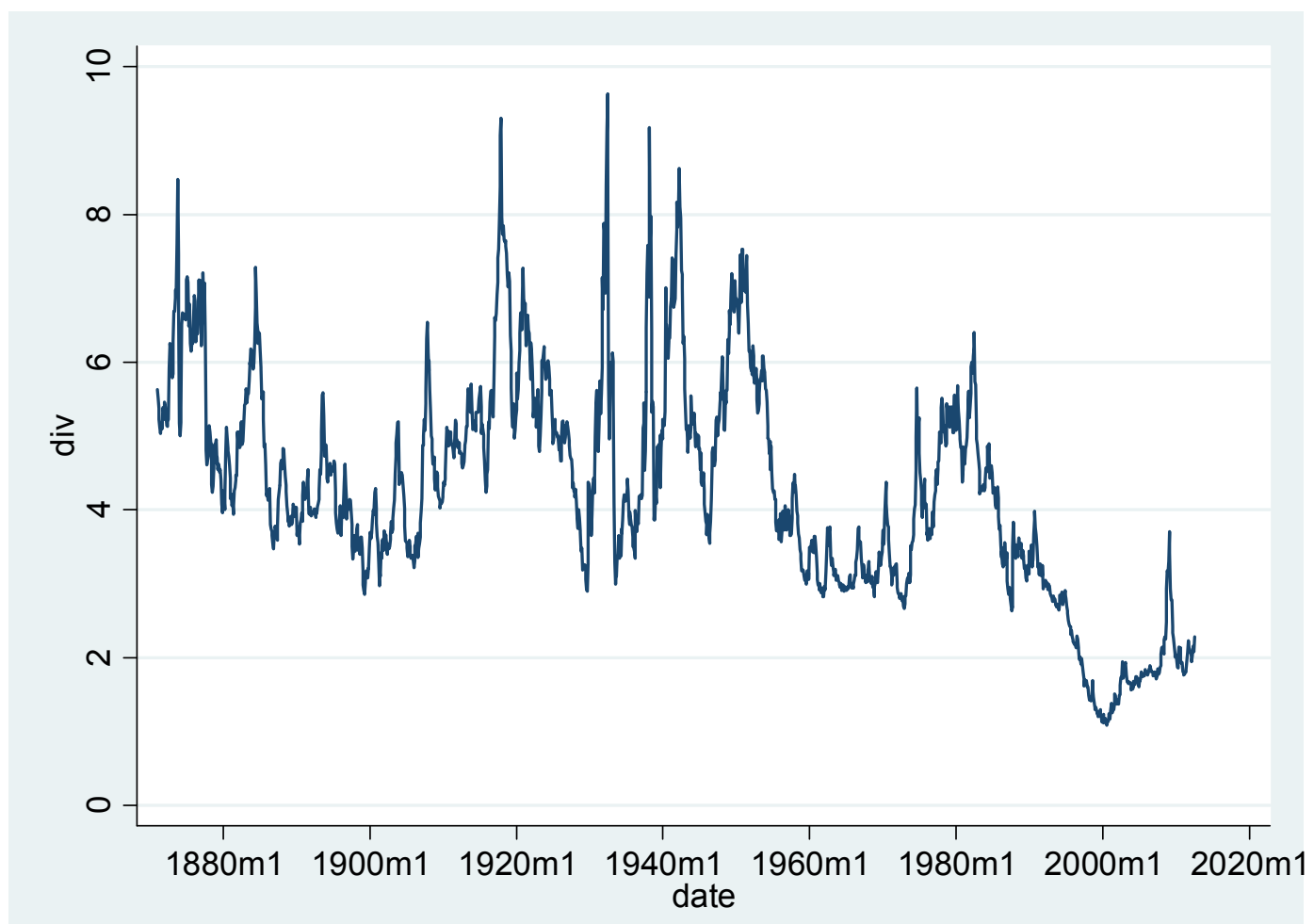

Figure 3.S\&P 500 Dividend Yield 


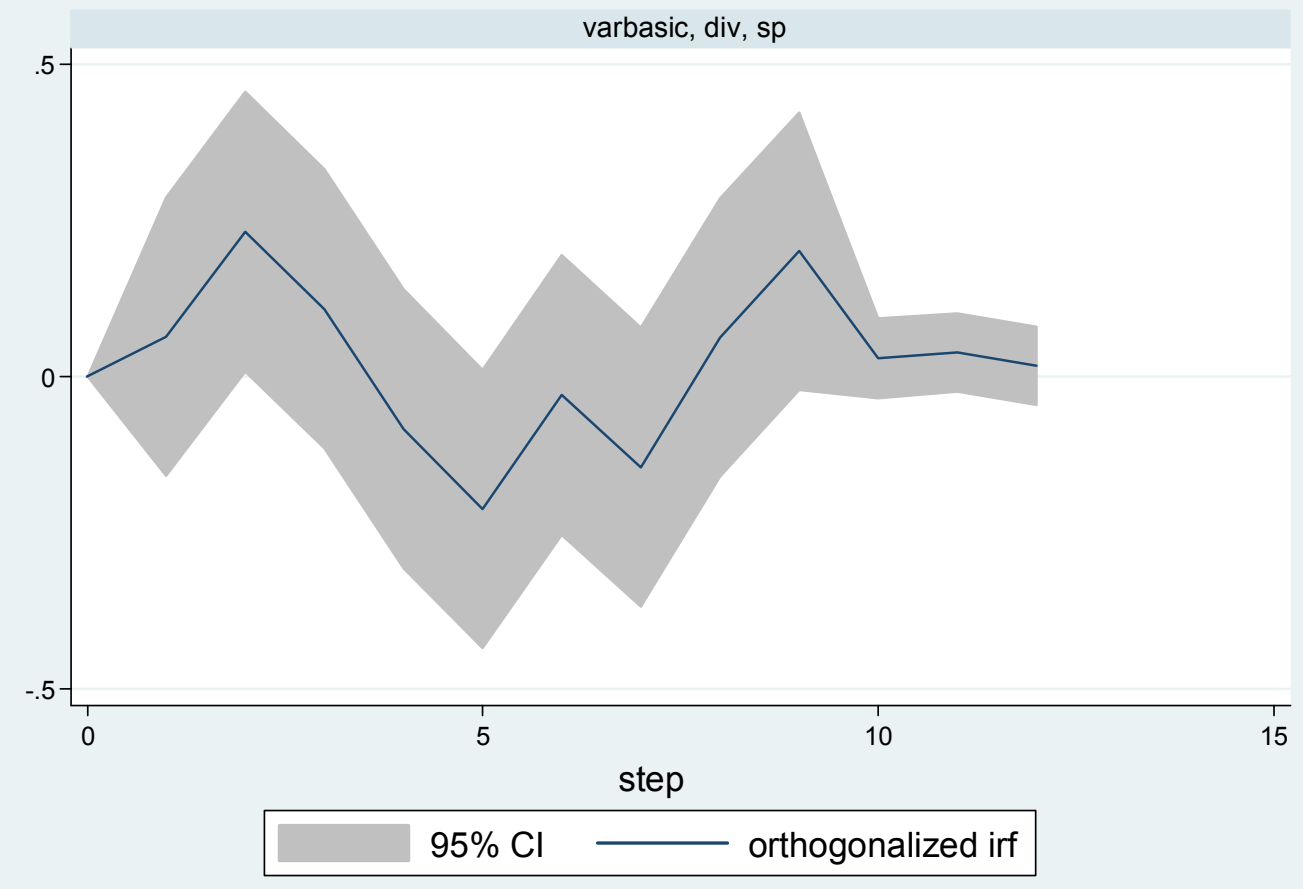

Graphs by irfname, impulse variable, and response variable

Figure 4. The Orthogonal Impulse Response Function (OIRF) of the Returns on the S\&P 500 Index to Dividend Yield Shock

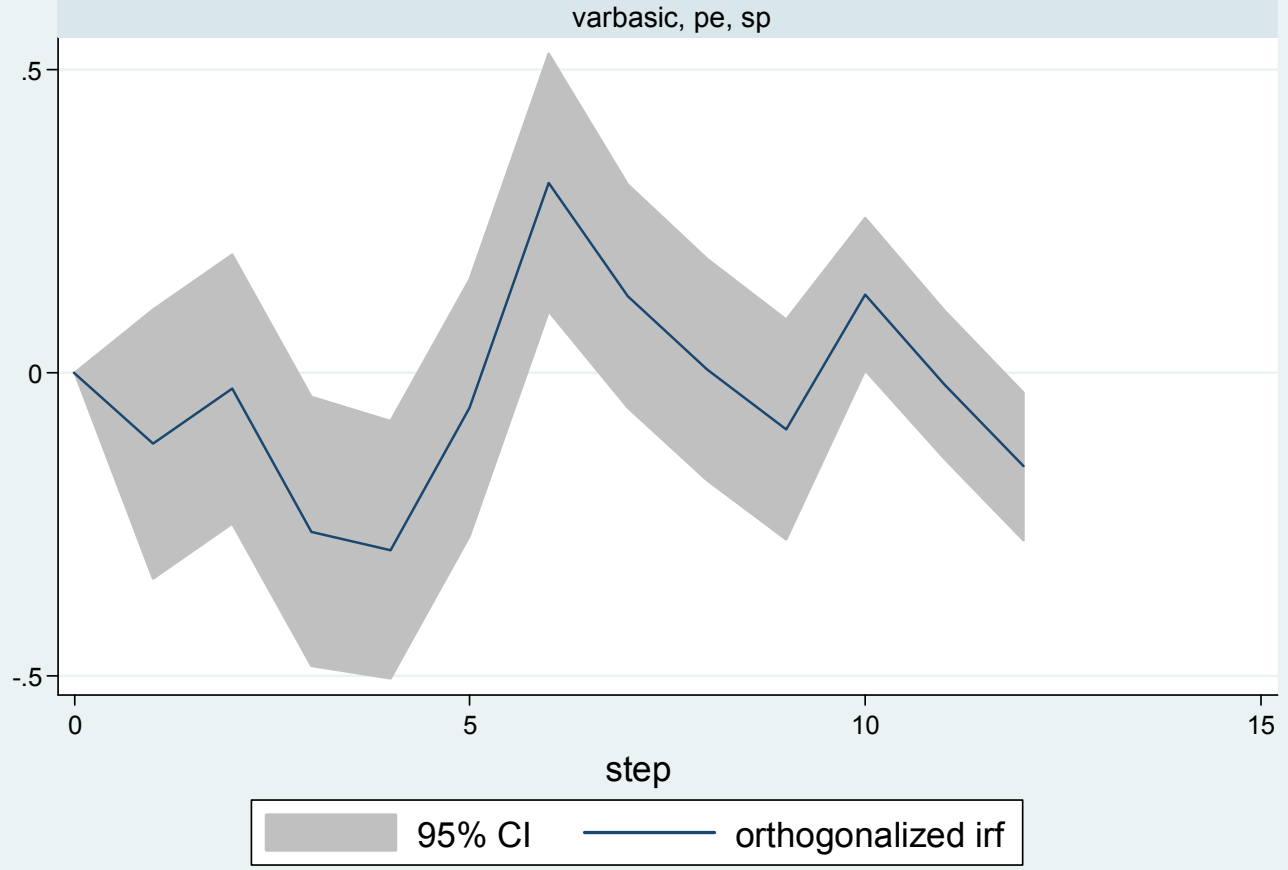

Graphs by irfname, impulse variable, and response variable

Figure 5. The Orthogonal Impulse Response Function (OIRF) of the Returns on the S\&P 500 Index to Price-to-Earning Shock 